\title{
Supplemental Irrigation through Drip in Kharif Maize + Redgram Intercropping System
}

\author{
V. Ramulu ${ }^{1}$, M. Devender Reddy ${ }^{2 *}$ and K. Avilkumar ${ }^{1}$ \\ ${ }^{1}$ Water Technology Center, Professor Jayashankar Telangana Agricultural University \\ Rajendranagar, Hyderabad - 500030 \\ ${ }^{2}$ M.S.Swaminathan School of Agriculture, Centurion University of Technology and \\ Management, Paralakhemundi, Odisha -761211, India \\ *Corresponding author
}

\section{A B S T R A C T}

\section{Keywords}

Inter cropping, Maize equivalent yield, Water productivity, Supplemental irrigation, Maize + red gram

\section{Article Info}

Accepted: 26 April 2020 Available Online: 10 May 2020

An experiment was conducted for three wet (kharif) seasons during 2008, 2009 and 2010 at the Agricultural College Farm, PJTSAU, Rajendranagar, Hyderabad to study the yield advantage and water productivity of supplemental irrigation to maize and red gram when grown as intercrops. There were three main treatments of irrigations - one supplemental irrigation each of $30 \mathrm{~mm}$ by drip at maize tasseling and red gram flowering, two supplemental irrigations of $30 \mathrm{~mm}$ of each by drip one each at maize tasseling and grain filling and red gram flowering and pod formation and Rain fed. These treatments were tested with combination four cropping systems - Sole Red gram, Sole Maize, Maize + Red gram intercropping (normal row) and Maize + Red gram intercropping (paired row) and replicated three times in strip plot design. The maize equivalent yield was significantly higher with two irrigations over that of one irrigation which in turn recorded significantly higher yield over rain fed. The water productivity was higher with two irrigations as compared to one and rain fed cropping. The water productivity was higher with Maize + Red gram normal planting followed by red gram sole crop, Maize + Red gram paired planting. The lowest water productivity was observed with maize sole cropping.

\section{Introduction}

Maize and red gram is grown as inter crops during Kharif under rain fed condition in sandy loam soils of Telangana and A.P. Maize because of its short duration, fast growing nature, proliferates well and utilizes more efficiently the available growth resources in the initial growth period. On the other hand, the long duration red gram is cultivated in wide row spacing and its slow growth in the initial period which facilitates growing of these two crops as intercrops which is a common practice in rain fed areas. For effective utilization of available growth resources and realize the income at least one 
crop in case failure of monsoons instead of complete crop loss, the inter cropping of red gram with other millets is practiced. In a situation where the monsoon distribution is uneven and many a times in occurs in Deccan peninsular India, there is possibility of terminal stress which coincides with flowering / seed formation stages in both the crops resulting in low yields or failure of one or both the crops. One of the approaches to counter measure to the unpredictability of rain and to overcome such problem is using supplementary irrigation during the growing season. Supplemental irrigation is a highly efficient option to achieve good yield by providing the crop with the needed amount of water at the required time (Oweis, 1997). Unlike full irrigation, the timing and amount of supplemental irrigation cannot be determined in advance, because it is supplementary to rainfall, which is variable in amount and distribution and difficult to predict (Oweis, 1999). Alleviating soil moisture stress during the critical crop growth stages is the key to improved production.

The chance of availability of abundant water supply for supplemental irrigation through surface methods of irrigation is very meager in drought prone areas. Hence, the application of limited available water more efficiently and economically through drip irrigation assumes importance. It is therefore a trial was conducted to study the water productivity and see the yield advantage of supplemental irrigation by drip in Kharif grown maize + red gram intercropping system.

\section{Materials and Methods}

An experiment was conducted for three wet (kharif) seasons during 2008, 2009 and 2010 at the Agricultural College Farm, PJTSAU, Rajendranagar, Hyderabad to study the yield advantage of supplemental irrigation to maize and red gram when grown as intercrops. The experimental soil was sandy loam with low $\mathrm{N}$, medium $\mathrm{P}$ and $\mathrm{K}$. The water holding capacity of the soil was $20 \%$. The experiment was conducted in strip plot design with three replications. The main treatments (Irrigations) constituted three levels of irrigation (one supplemental irrigation each of $30 \mathrm{~mm}$ by drip at maize tasseling and red gram flowering, two supplemental irrigations of 30 $\mathrm{mm}$ of each by drip one each at maize tasseling and grain filling and redg ram flowering and pod formation and Rain fed. The Sub-treatments (Cropping Systems) tried were - Sole Red gram, Sole Maize, Maize + Red gram intercropping (normal row) and Maize + Red gram intercropping (paired row). The red gram variety LRG-41 and maize variety Cargil DEKLAB $900 \mathrm{M}$ was sown on 5-7-2008, 16-07-09, 19-7-2010. The maize inter cropping was adopted as an additional series. The maize in normal planting was sown at $60 \mathrm{~cm} \times 30 \mathrm{~cm}$, while red gram was sown at $120 \mathrm{~cm}$ x $30 \mathrm{~cm}$ spacing. For every two rows of maize one row of red gram was sown. In paired planting the spacing adopted was $40 \mathrm{~cm} \times 30 \mathrm{~cm}$ between two pairs of maize and one row of red gram was planted between two rows of maize. The maize crop was fertilized with 100:50:40 $\mathrm{kg} \mathrm{N}, \mathrm{P}_{2} \mathrm{O}_{5}$ and $\mathrm{K}_{2} \mathrm{O} \mathrm{ha}^{-1}$ and red gram with $20: 50 \mathrm{~kg} \mathrm{~N}$ and $\mathrm{K}_{2} \mathrm{O} /$ ha.

The recommended $\mathrm{P}_{2} \mathrm{O}_{5}$ and $\mathrm{K}_{2} \mathrm{O}$ of maize (RDF: Maize - 100:50:40 kg N, $\mathrm{P}_{2} \mathrm{O}_{5}$ and $\mathrm{K}_{2} \mathrm{O} \mathrm{ha}{ }^{-1}$ ) and entire level of recommended fertilizer to red gram (Red gram $-20: 50 \mathrm{~kg} \mathrm{~N}$ and $\mathrm{K}_{2} \mathrm{O} \mathrm{ha} \mathrm{ha}^{-1}$ ) were applied in the form of super phosphate and mureate of potash to respective crops near the seed at the time of sowing. The recommended level of $\mathrm{N}$ to maize crop was applied in three splits $1 / 3$ each at sowing, knee high stage and taselling stage of maize crop in the form of urea. One manual weeding was done between 30-35 days after sowing 
The total rain fall received during June to October was 911, 601 and $948 \mathrm{~mm}$ in 38, 33 and 55 rainy days in 2008, 2009 and 2010, respectively. Rainfall distribution was more or less uniform in 2008 and 2010 (Fig. 1) but in 2009, comparatively dry period prevailed in the initial crop period (July and August). In 2009, maize crop failed due to early dry spell in the season, to save the crop from the prevailing dry spell in the month of August, an amount of $54 \mathrm{~mm}$ of water was applied uniformly to all the treatments. In 2010 since no dry spell was prevailed and the field was near field capacity level at full bloom stage in maize hence no supplementary irrigation was given. The irrigation water was applied to each plot through HDPE pipe to which water meter was attached for measurement of water. The effective rainfall was estimated by using CRIWAR method. The water table was more than $4 \mathrm{~m}$ below the surface during 2008 and 2009 and it was around $2 \mathrm{~m}$ below the ground level for nearly three months crop growing period in 2010. The entire net plot was harvested threshed and grain yield was determined at $14 \%$ moisture content.

The water productivity (WP) (kg maize equivalent grain yield $\mathrm{m}^{-3}$ of water) was calculated by

$\mathrm{WP}=\mathrm{Y} / \mathrm{WA}_{(\mathrm{IR}+\mathrm{ER})}$

Where $\mathrm{Y}=$ maize grain equivalent yield $(\mathrm{kg}$ ha-1), and WA (total water used) = (IRirrigation + ER- effective rainfall)

\section{Results and Discussion}

\section{Individual crop yields}

The individual crop yield of red gram and maize were higher than that grown as inter crop of Maize + Red gram either in normal planting or in paired planting. Further, the individual crop yields of red gram or maize were lower in paired planting as compared to normal planting (Table 1). Similar trend was observed when one or two supplemental irrigations were provided through drip to each crop.

\section{Maize Equivalent Yield (MEY)}

For calculation of maize equivalent yields, the prices of maize and red gram considered in 2009-10, and 2010-11 for $100 \mathrm{~kg}$ of economic produce was Rs 900 for maize and Rs.3500 for red gram and In 2008-09, for $100 \mathrm{~kg}$ of economic produce was Rs 787 for maize, and Rs.3143 for red gram.

The red gram yields in different treatments were converted to maize equivalent yields by taking in to consideration of MSP of that particular year (Table 2). There was significant difference between different supplemental irrigation regimes, cropping systems, interaction of cropping systems and irrigation regimes and year. The maize equivalent yield was significantly higher with two irrigations over that of one irrigation which in turn recorded significantly higher yield over rain fed.

The maize equivalent yield was significantly higher with red gram + maize cropping system under conventional planting over that of maize + Red gram in paired row planting and pure crop of red gram (Table 2). The maize equivalent yield in latter two treatments was comparable and significantly higher than that of sole maize crop.

The interaction effect of cropping system and irrigation levels on grain yield was significant. Under sole red gram cropping, the MEY of rain fed crop red gram was comparable with one irrigation and significantly superior over that under two irrigations. The MEY in latter two irrigation levels was comparable with each other. The 
MEY of sole maize cropping did not differ significantly at different irrigation levels. Under maize + red gram normal planting, the MEY was significantly higher with two irrigations over one irrigation which in turn recorded significantly higher MEY over rain fed cropping. Under paired planting of Maize +red gram, the MEY of rain fed crop was comparable with one irrigation and significantly lower than that under two irrigations. The MEY under latter two irrigation treatments was comparable.

Under rain fed conditions, the MEY of sole red gram, maize + red gram with normal and paired planting was comparable with each other and significantly higher over sole maize. The MEY of one and two irrigations with sole red gram red gram + maize paired planting was comparable and significantly higher than sole maize. The MEY in the former cropping systems was significantly lower than the MEY recorded under red gram + maize normal planting.

\section{Water productivity}

The quantity of water applied under one and two irrigations were 51 and $90 \mathrm{~mm}$ respectively. In 2009, dry period prevailed in the initial crop period (July and August) and maize crop suffered and to save the crop from the prolonged dry spell in the month of August; an amount of $54 \mathrm{~mm}$ of water was applied uniformly to all the treatments.

The water productivity was higher with two irrigations as compared one and rain fed cropping (Table 3). Provision of one irrigation resulted higher productivity than rain fed crop. The water productivity was higher with red gram + maize normal planting followed by red gram sole crop, red gram + maize paired planting. The lowest water productivity was observed with maize sole cropping.

It is not the seasonal rainfall, the distribution of rain fall is most important. During 2010 where the rain fall distribution was good and crop does not experience any stress, the MEY was 39.6 and $60 \%$ higher over that of year 2009 and 2008 (Table 2). Though the crop experienced stress in 2009, the red gram performed better than other seasons. Hence, MEY of 2009 was higher than 2008.

Fig.1 Weekly rainfall received during kharif seasons of 2008, 2009 and 2010 at Rajendranagar, Hyderabad

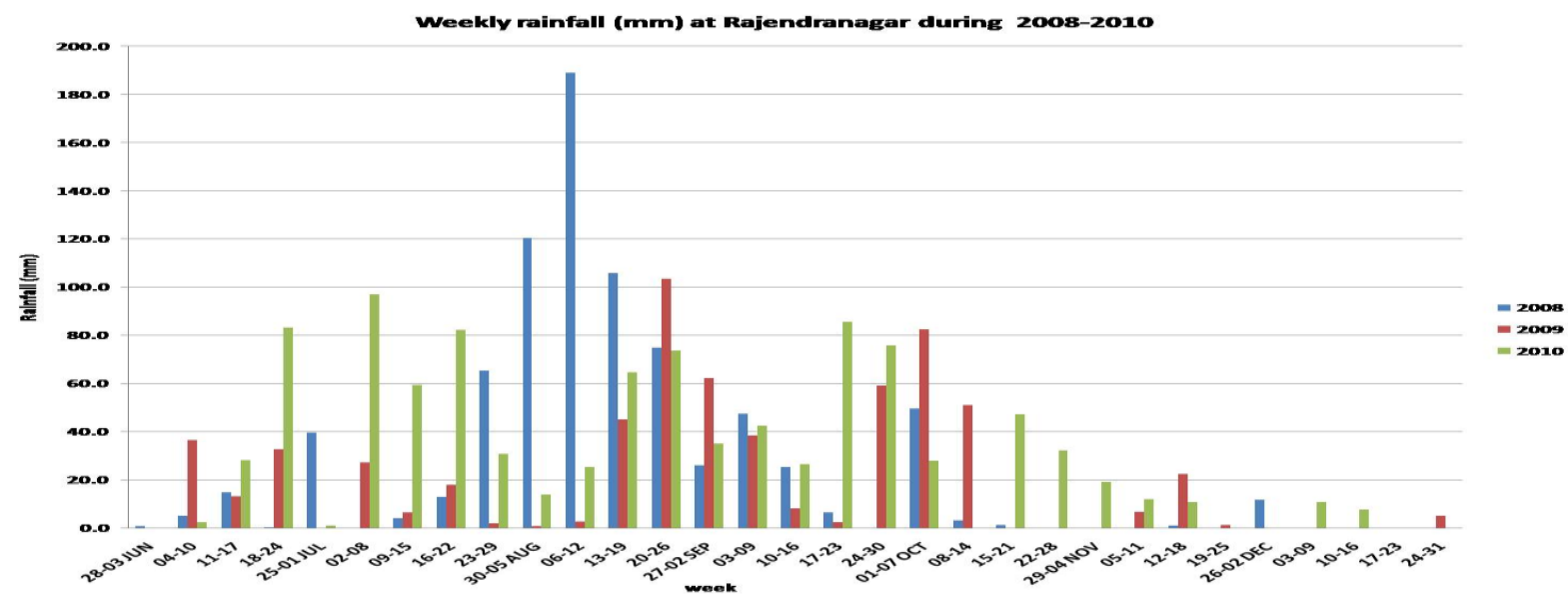


Table.1 Grain / seed yield of red gram and maize individual crops in Maize-Redgram intercropping system (Mean of 2008, 2009 and 2010)

\begin{tabular}{|l|c|c|c|c|}
\hline \multicolumn{1}{|c|}{ Cropping system } & \multicolumn{2}{|c|}{ Supplemental irrigation } & \multirow{2}{*}{ Mean } \\
\cline { 2 - 5 } & Rain fed & $\begin{array}{c}\text { 1 Irrigation each to } \\
\text { maize and redgram }\end{array}$ & $\begin{array}{c}\text { 2 Irrigations to } \\
\text { maize and redgram }\end{array}$ \\
\hline Sole Redgram & 1.64 & 1.86 & 1.87 & 1.79 \\
\hline Sole Maize & 2.61 & 2.37 & 2.40 & 2.46 \\
\hline Red gram + Maize & $1.12+2.05$ & $1.67+2.2$ & $2.16+2.82$ & $1.65+2.36$ \\
\hline $\begin{array}{l}\text { Red gram + Maize } \\
\text { (paired row) }\end{array}$ & $0.61+1.90$ & $1.42+2.07$ & $1.28+2.07$ & $1.10+2.01$ \\
\hline
\end{tabular}

Table.2 Maize-Red gram intercropping system influence on Maize equivalent yield (t/ha) under supplemental irrigation

\begin{tabular}{|c|c|c|c|c|c|}
\hline \multirow{2}{*}{$\begin{array}{l}\text { Treatments } \\
\text { Irrigation } \\
\text { (Main plot) }\end{array}$} & \multicolumn{4}{|c|}{ Cropping system (Sub plot) } & \multirow{2}{*}{$\begin{array}{l}\text { Mean, Maize } \\
\text { equivalent } \\
\text { yield, t ha-1 }\end{array}$} \\
\hline & $\begin{array}{l}\text { Sole } \\
\text { Redgram }\end{array}$ & Sole Maize & $\begin{array}{l}\text { Maize + } \\
\text { Red gram }\end{array}$ & $\begin{array}{l}\text { Maize + } \\
\text { Red gram } \\
\text { (paired row) }\end{array}$ & \\
\hline Rainfed & 6.43 & 2.61 & 6.24 & 6.02 & 5.33 \\
\hline One irrigation & 7.26 & 2.37 & 8.70 & 6.51 & 6.21 \\
\hline Two irrigations & 7.34 & 2.40 & 10.67 & 7.05 & 6.87 \\
\hline Mean & 7.01 & 2.46 & 8.54 & 6.53 & \\
\hline \multicolumn{6}{|l|}{ Year } \\
\hline 2008-09 & & & & & 4.91 \\
\hline 2009-10 & & & & & 5.63 \\
\hline \multirow[t]{2}{*}{ 2010-11 } & & & & & 7.86 \\
\hline & & & S.Em.+/- & $\mathrm{CD}$ at $5 \%$ & \\
\hline \multicolumn{2}{|l|}{ year } & & 0.43 & 1.24 & \\
\hline \multicolumn{2}{|l|}{ Irrigation } & & 0.08 & 0.31 & \\
\hline \multicolumn{2}{|l|}{ Cropping system } & & 0.25 & 0.74 & \\
\hline \multicolumn{2}{|c|}{$\begin{array}{l}\text { Interaction of irrigation and } \\
\text { cropping system }\end{array}$} & & 0.29 & 0.85 & \\
\hline
\end{tabular}


Table.3 Water productivity as influenced by supplemental drip irrigation in Maize-Redgram intercropping (Mean of 2008, 2009 and 2010)

\begin{tabular}{|c|c|c|c|c|c|c|}
\hline \multirow[t]{3}{*}{ Treatments } & \multirow{2}{*}{\multicolumn{2}{|c|}{$\begin{array}{l}\text { Quantity of water } \\
\text { applied }\end{array}$}} & \multirow{2}{*}{\multicolumn{2}{|c|}{$\begin{array}{l}\text { Total water } \\
\text { consumed }\end{array}$}} & \multicolumn{2}{|c|}{ Maize equivalent } \\
\hline & & & & & \multirow{2}{*}{$\begin{array}{l}\text { Yield, } \\
\text { t ha }^{-1}\end{array}$} & \multirow{2}{*}{$\begin{array}{l}\text { Water productivity } \\
\qquad\left(\mathrm{Kg} \mathrm{m}^{-3}\right)\end{array}$} \\
\hline & $\mathrm{mm}$ & $\begin{array}{c}\text { Effective } \\
\text { rainfall }(\mathrm{mm})\end{array}$ & $\mathrm{mm}$ & $\mathrm{M}^{3}$ & & \\
\hline \multicolumn{7}{|l|}{ Irrigation } \\
\hline Rainfed & 18 & 477 & 495 & 4950 & 5.33 & 1.08 \\
\hline One irrigation & 51 & 477 & 528 & 5280 & 6.21 & 1.18 \\
\hline Two irrigations & 90 & 477 & 568 & 5680 & 6.87 & 1.21 \\
\hline \multicolumn{7}{|l|}{ Cropping system } \\
\hline Sole Redgram & 53 & 477 & 530 & 5300 & 7.01 & 1.32 \\
\hline Sole Maize & 53 & 477 & 530 & 5300 & 2.46 & 0.46 \\
\hline Maize + Red gram & 53 & 477 & 530 & 5300 & 8.54 & 1.61 \\
\hline $\begin{array}{l}\text { Maize }+ \text { Red gram } \\
\text { (paired row) }\end{array}$ & 53 & 477 & 530 & 5300 & 6.53 & 1.23 \\
\hline
\end{tabular}

These results indicate that the supplemental irrigation plays a major role in increasing water use efficiency and yields of rain-fed crops indicating addition of limited amounts of water to rainfed crops improves yields when rainfall fails to provide sufficient moisture for normal plant growth. It was reported an increase in $37-38 \%$ of sorghum yield with supplemental irrigation at two separate locations with rain fall ranging from 418-667 $\mathrm{mm}$ and 196-557 mm (Rockström et al., 2002). Further, the total yields in intercropping treatment irrigated with $35 \mathrm{~mm}$ of drip during the heading stage of wheat and the heading and anthesis stage of maize were the highest, followed by that irrigated during the anthesis stage of wheat and the silking stage of maize; so was the water use efficiency (Bu. Chong Zhang et al., 2007). Further, the high variability in rainfall during the wet season which leads to considerable variability in the expected yield for rainfed conditions was significantly reduced when supplemental irrigation with water of about $150 \mathrm{~mm}$ was provided to maize crop (Agossou Gadédjisso-Tossou et al., 2018)
For red gram, Saraf and Ahlawat (1975) emphasized that one irrigation before flowering is very critical to compensate the failure of winter rains under north Indian conditions and to realize higher yield. According to Chauhan (1990), application of three irrigations doubled seed yields of pigeon pea in Alfisols. It has been reported that significant grain yield advantage with single drip- fertigation with half of $\mathrm{N}+\mathrm{K}$ fertilizer at branching was observed over farmers' practice (Praharaj et al., 2017). These results further confirmed that depending on water stress, supplementary irrigation was helpful in up-scaling grain yield (Praharaj et al., 2014, Praharaj et al., 2013 and Ramamurthy, 2009). The results of this experiment are also in conformity to the findings of Rao et al., (1983) where application of one or two protective irrigations during the critical growth stages of pigeon pea (flowering and pod formation) produced higher yields.

From the three years study, it can be concluded that two supplemental irrigations to red gram + maize at critical stages of maize 
and red gram improve the yield and water productivity. Small quantity of water need to be made available with drip irrigation for getting increased yield of maize and red gram inters cropping system.

\section{References}

Agossou Gadédjisso-Tossou, Tamara Avellán and Niels Schütze. 2018. Potential of Deficit and Supplemental Irrigation under Climate Variability in Northern Togo, West Africa. 2018. Water 2018, 10, 1803; doi: 10.3390/w10121803

BC Zhang, GB Huang, LI Feng-Min Pedosphere, 2007. Effect of limited single irrigation on yield of winter wheat and spring maize relay intercropping. Pedosphere 17(4): 529537.

Chauhan, Y.S. 1990. A ready-reckoner to help pigeonpea researchers determine plant population. International Pigeonpea Newsletter. 11: 14-15. ISSN 0255-786X.

Oweis, T. 1997. Supplemental irrigation: A highly efficient water-use practice. ICARDA. Aleppo, Syria.

Oweis, T. 1999. Water harvesting and supplemental irrigation for improved water use efficiency in dry areas. Colombo, Sri Lanka: IWMI.

Praharaj, C. S., 2013. Managing precious water through need based microirrigation in a long duration pigeonpea under Indian Plains. In Proceeding of the International Conference on Policies for Water and Food Security, Cairo, Egypt, 24-26 June 2013, p. 4.

Praharaj, C. S., Singh, U. and Hazra, K., 2014. Technological interventions for strategic management of water for conserving natural resources. In Proceeding of 6th World Congress on Conservation Agriculture - Soil Health and Wallet Wealth, Winnipeg, Manitoba, Canada, 22-26 June 2014, p. 3.

Ramamurthy, V., Patil, N. G., Venugopalan, M. V. and Challa, O., 2009. Effect of drip irrigation on productivity and water-use efficiency of hybrid cotton (Gossypium hirsutum) in Typic Haplusterts. Indian J. Agric. Sci., 79, 118-121.

Rao, I., Madhusudana, V.N., Venkataratnam, N., Faris, D.G and Sheldrake, A.R. 1983. Response to irrigation in post rainy-season pigeonpea. International Pigeonpea Newsletter. 2: 35-36

Rockström, J., Barron, J., \& Fox, P. 2002. Rainwater management for increased productivity among small-holder farmers in drought-prone environments. Physics and Chemistry of the

Earth, Parts A/B/C, 27, 949-959. doi:10.1016/S1474- 7065(02)00098-0

Saraf, C.S and Ahlawat, I.P.S. 1975. Review of recent and pulse crops, water management practices. Indian Journal of Agricultural Research. 9(1): 1-6.

\section{How to cite this article:}

Ramulu, V., M. Devender Reddy and Avilkumar, K. 2020. Supplemental Irrigation through Drip in Kharif Maize + Redgram Intercropping System. Int.J.Curr.Microbiol.App.Sci. 9(05): 3014-3020. doi: https://doi.org/10.20546/ijcmas.2020.905.358 